\section{Fresner J., Krenn C., Kleshchov A., Tomasi F.}

\title{
EXPLORATORY RESEARCH INTO ENERGY EFFICIENCY INVESTMENT AND STRATEGY
}

Об'єктом дослідження є процес впровадження енергоефективних заходів на промислових підприємствах. Одним з найбільш проблемних місць є зафіксований тренд зменшення інвестицій в сферу енергоефективності. Встановлено, що після кількох років зростання, глобальні інвестицї в енергоефективність та відновлювані джерела енергї почали скорочуватись у 2017 рочі. За даними Міжнародного енергетичного агентства, існує ризик того, що тренд зменшення інвестицій буде продовжуватись. В рамках проекту PINE в Австрії було проведено 20 енергетичних аудитів, в результаті яких було запропоновано впровадити заходи, направлені на енергоефективність. За результатами проекту було проаналізовано та аргументовано зв'язок між інвестуванням і впровадженням заходів з енергоефективності та життєвим циклом, та типом підприємств, які впроваджено у компаніях різних галузей. Встановлено, що близько $50 \%$ ідентифікованих заощаджень електроенергї від впровадження заходів є результатом застосування частотного керування приводів, усунення витоків стисненого повітря або модернізацї систем освітлення. Це дозволило розробити раціональні бізнес та політичні стратегї для підприємств на різних етапах життєвого циклу. Проаналізовано підхід, орієнтований на одиничні операцї, обраний у иій програмі та який полегшує виявлення зв'язків між споживанням енергї̈ виробничими підрозділами та технологічно-організаційними чинниками, що впливають на ї споживання. Наукова новизна дослідження виражається в обгрунтуванні критичних стратегічних перешкод у сфері інвестищій в енергоефективні рішення, що дозволило запропонувати рачіональні бізнес-стратегї та відповідні заходи політичної підтримки для їх подолання. Через те, що підприємства з однаковими вхідними та вихідними ресурсами можуть мати різний технологічний цикл, терміни окупності однакових впроваджених заходів можуть бути різними. Аналіз реального досвіду збереження енергоресурсів із розробленими бізнес стратегіями та стратегіями політичної підтримки дозволить ефективно поширити його у країнах Європи.

Ключові слова: інвестиційні бар'єри, енергетичні аудити, збереження енергоресурсів, енергоефективні заходи, цільове втручання, нематеріальні прибутки.

\section{Introduction}

The report of the International Energy Agency [1] finds that after years of growth, combined global investment in renewables and energy efficiency declined by $3 \%$ in 2017. Efficiency investment growth has again weakened in 2018 [2]. This is observed in spite of various authors demonstrating that there is a serious potential for energy efficiency in many industries [3] and significant potential for renewable energy [4]. Over two-thirds of efficiency potential is still untouched [5]. In 2017, the world spends about EUR 200 billion on energy efficiency. This was invested largely on heating, cooling and lighting improvements in buildings.

Tapping the full potential of energy efficiency will require at least four times as much investment than is spent at present. The International Energy Agency warns these investments are actually slowing down, partly due to the slow implementation of energy efficiency policies. Energy efficiency should be considered as a basis of energy policies at all levels of policies, because of its proven status as a cost-effective option for reducing $\mathrm{CO}_{2}$ emissions. Politics should establish the necessary foundation to capture all cost-effective energy efficiency measures [6]. Innovation and creativity are necessary to unlock energy efficiency investments and to grasp the associated employment and growth opportunities. Therefore, development of the rational business and political strategies for implementation of the energy-efficiency at different enterprises is actual.

\section{The object of research and its technological audit}

The object of research is the process of implementing energy-efficient measures at industrial enterprises. The main condition for implementation of different technical measures or business strategies in Ukraine is standard. It is no matter in what stage of life cycle is enterprise, the technical measures for all of them will be promoted the same (modernization of the lightning system, thermo insulation of building, changing compressed air systems on the electric systems etc.). But, because of this, not all companies could receive profit.

To identify rational strategies for companies with different stage of life cycle, it is necessary to provide energy audit for different companies and to monitor their state after the implementation of proposed measures. That is why, one of the biggest problem areas is the absence of the statistical data and analysis, which will explain the link between investment and implementation of measures on energy efficiency and life cycle and type of enterprises implemented in companies of different industries. 


\section{The aim and objectives of research}

The aim of research is to investigate potential strategical reasons and appropriate measures to overcome the apparent gap in investment in energy efficiency.

To achieve this aim, the following objectives are accomplished:

1. To summarize barriers to the implementation of energy efficiency measures.

2. To develop business strategy to increase energy efficiency level at different types of companies.

3. To propose political strategy of supporting energy efficiency measures implementation.

\section{Research of existing solutions of the problem}

In this section, an analysis of relevant literature describing relevant barriers into energy efficiency investment in industry is presented. It is shown that a number of interrelated barriers to energy efficiency investment are already identified in a variety of published studies. The majority of authors consider profitability as the main barrier. The most relevant economic and financial barriers for investing into industrial energy efficiency are according to the Department of Energy (USA) [7]:

- payback time;

- volatility of energy prices;

- competition for capital;

- failure to recognize non-monetary benefits of energy efficiency.

An additional reason is the generally low relevance of energy cost in production companies.

Other empirically observed categories of barriers include: lack of full information, lack of time, lack of staff, low priority, and lack in long term strategy, according to [8]. This research found that size of companies, the implementation of an energy management system, autonomy of the enterprise, and relatedness to the customer are other important impact factors in investment decisions into energy efficiency. These barriers are described in more detail below.

Several authors agree that decision on energy efficiency or renewable energy investment is taken mostly evaluating payback of investment [9]. Calculation of simple payback is one of the most common methods to evaluate a capital investment, especially among engineers. The payback period of an investment is defined as the period of time in which the initial capital expenditure is recovered. Payback frequently is used as a first assessment whether detailed planning is worth-while [10]. Methodologically, the payback period does not include risk assessment and ignores the time value of money [11]. This approach does not consider the time value of cash flows, risk assessment or investment strategy.

The maximum acceptable payback is usually determined by a management decision and not based on a specific economic or scientific foundation. Production companies often have limited capital available for efficiency projects and frequently require very short payback periods of one to three years [12, 13]. Larger companies, or owner-managed companies, sometimes accept 3-year paybacks. Required payback times depend also on the type of equipment (Table 1). In any case payback has to be shorter than the remaining useful life of the equipment, which is not shown in the previous works.
Rule-of-thumb recommendations for payback times*

Table 1

\begin{tabular}{|l|c|}
\hline \multicolumn{1}{|c|}{ Type of investment } & $\begin{array}{c}\text { Recommen- } \\
\text { ded payback } \\
\text { time (years) }\end{array}$ \\
\hline Small electronic equipment & $1-2.5$ \\
\hline Efficiency improvement & $2-3$ \\
\hline Small to medium industrial plant and equipment & $2-5$ \\
\hline Mobile plant and equipment & $2-5$ \\
\hline Medium to large plant and equipment & $2-5$ \\
\hline Market extension & 5 \\
\hline New product in new market & 6 \\
\hline Medium to large production plant & $5-10$ \\
\hline Large production facilities and high tech production facilities & $10-15$ \\
\hline Large scale mining projects & $10-20$ \\
\hline Safety or ather legal requirement & No test \\
\hline
\end{tabular}

Note: * - compiled by the authors based on the data [14]

As the payback becomes longer, however, the more likely unexpected changes might render the project not profitable [15]. But in this case, authors didn't consider a link to strategical aspects, like growth of market share or development of new products.

Volatile energy prices will make decisions to invest into energy efficiency riskier, because savings out of the investment become less certain [16]. For example, in Austria energy prices show volatility. Natural gas prices peaked in 2013 to about $80 \%$ of the peak until 2017 for medium sized industry, according to Eurostat [17]. Since then, they declined (Table 2). Because of this, it is difficult to use payback as a criterion. Labor cost has increased by $40 \%$ from 2000 (23.1 EUR/hour) to 2015 (32.4 EUR/hour) in Austria [18]. The producer price index for investment goods in Austria has increased by $10 \%$ in the same period [17]. As a result, payback times for investment into energy efficiency in general have become longer.

Table 2

Natural gas price and natural gas price index for Austria, 2018*

\begin{tabular}{|c|c|c|}
\hline Year & $\begin{array}{c}\text { Natural gas price medium } \\
\text { sized industry (EUR/GJ) }\end{array}$ & $\begin{array}{c}\text { Natural gas price index medium } \\
\text { sized industry (\%; 2007=100 \%) }\end{array}$ \\
\hline 2007 & 8.9 & 100 \\
\hline 2009 & 8.6 & 97 \\
\hline 2011 & 9.0 & 101 \\
\hline 2013 & 9.7 & 109 \\
\hline 2015 & 8.5 & 96 \\
\hline 2017 & 7.4 & 83 \\
\hline
\end{tabular}

Note: * - compiled by the authors based on the data [17]

In the work [19] it has been explained, why some firms may choose not to undertake investments in energy saving technologies although they may appear profitable from a payback perspective. As future technological advances are inherently uncertain, it may pay to postpone investments in energy saving and wait for improved varieties of equipment. But, the authors did not go into details regarding the motivation for investment out of targeted strategic considerations. 
Although the fact that industry typically insists on a two-year payback period for energy efficiency is frequently criticized the reality is that it can be entirely rational to apply this period considering:

- uncertainty in actual savings as a result of the investment;

- uncertainty about future production;

- existence of competing strategic investments such as new production plants, new products or marketing. Industrial firms do not make investment decisions related to energy separately from other aspects of operations. Measures which result in loss of production are usually not accepted. They are considered too much of a risk to the general business. Energy savings are perceived as side effect of other investments rather than as an independent value-generating activity [7]. From this aspect, it can be concluded that energy efficiency is always closely linked to the more general concept of resource efficiency.

The results from $[9,20]$ indicate that in industry, priorities are higher to production than to energy consumption.

Energy efficiency cannot be directly measured in terms of production increase. It is measured as a saving against a baseline of consumption. Financial institutions are likely to perceive renewables and energy efficiency as risky, leading to higher interest rates and the request for collaterals. The intangible and comparatively small nature of energy efficiency assets and projects discourage traditional investors.

In Austria, industrial investments in general have been sinking over the last 10 years [21]. From this, it can be concluded that in times of general lower investment also investment into activities, which apparently are not directly linked to productivity, is lower.

Several authors identified that there are other relevant barriers apart from financial barriers. Non-financial practical barriers include limited in-house skills, according to $[22,23]$. They also include expertise to identify [21] and implement energy saving projects [22, 23]. In [24] it is shown that difficulty in gathering external skills and lack of time of the barriers. Lack of information on cost and benefits, difficulties in assessing the risks associated with the intervention, and no trust in the information sources emerged as primary barriers in the findings of $[25,26]$.

Investment in energy efficiency can provide various benefits to different stakeholders, by directly reducing energy demand and associated costs, which can enable investment in other goods and services [4]. Not considering non-energy or co-benefits of an energy efficiency project will neglect potentially relevant aspects of the business case of energy efficiency investments. Again, this research did not establish the link of energy efficiency to existing managerial or strategical priorities.

Industrial energy efficiency measures may deliver substantial benefits in addition to energy cost savings - enhancing competitiveness, profitability, production and product quality, reduced maintenance, improving the working environment, and for environmental compliance. The multiple benefits approach to energy efficiency seeks to expand the perspective of energy efficiency beyond the traditional measures of reduced energy demand by identifying and measuring its impacts across other spheres.

In the work [27] it has been suggested that quantifying non-energy benefits can help showing the full potential of energy-efficient technologies and increase the probability of adoption. The authors of the [27] cover the investment behavior for energy-efficiency investments assessing on what basis investment decisions are made. A survey of 200 companies which had implemented energy efficiency measures showed the following results [28]:

- main drivers for the implementation of energy efficiency are reduction of cost and increase of productivity, while corporate reputation and government regulations remain low on the list of influencing factors;

- cost control is over five times more likely to be a driver of energy efficiency initiatives than compliance with government regulations, according to the organizations surveyed;

- $76 \%$ of respondents recognized that other benefits additionally to energy savings are achieved through energy efficiency projects.

Introducing benefits like energy security, and reduced risk for health and safety can help to better align energy efficiency with strategic business priorities, thereby strengthening the business case for investment. Other benefits like the reduction of greenhouse gases, air pollution, employment and poverty alleviation are mainly relevant on a macroeconomic level. Inclusion of these benefits within the investment criteria of an energy efficiency project is still not widely applied [4].

The relevance of energy cost for industry is generally low, as data for Germany reveal (Table 3): showing the savings reliably therefore becomes difficult. The result is perceived complexity for monitoring and verification to confirm the savings.

Table 3

Average cost contribution in German processing industry*

\begin{tabular}{|l|c|}
\hline \multicolumn{1}{|c|}{ Cost contribution } & Percent (\%) \\
\hline Energy & 2 \\
\hline Commodities & 13 \\
\hline Labor & 19 \\
\hline Material & 42 \\
\hline Other cost (Depreciation, capital cost, taxes, profit) & 24 \\
\hline
\end{tabular}

Note: * compiled by the authors based on the data [29]

There is, of course, a wide variation in energy cost depending on the production sector, which was not mentioned in the [29]. In minerals, metals smelting, dyeing and finishing in the textile industry energy cost is more likely to be in the range of $10 \%$ or more of the overall expenses [30].

Other authors suggest that decisions on investment into energy efficiency can be related to a company's strategy. The investigation [20] founds interviewing energy managers that a relevant barrier results from lack in influence of the people in charge of energy management. Higher priorities than to energy efficiency are assigned to production activity. It has been recognized the negative impact of management resistance to change, inadequate management capacity, and conflicts of interest within the organization.

Authors of the work [31] have investigated the question whether energy efficiency investments depend on company characteristics rather than profitability of the investment and answered it affirmatively. The most relevant paper dealing with the relevance of strategic considerations is the research of [32]. It developed an investment decision-making model showing four levels of barriers (Fig. 1) and tested it empirically with 28 companies. It appears from the empirical research that strategy is more influential than profitability. Profitability apparently is a generally necessary but insufficient condition. 


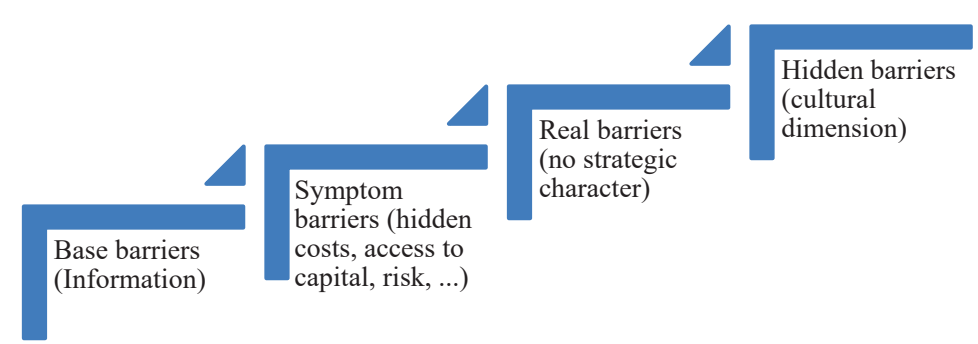

Fig. 1. Barriers to energy efficiency investment (modified from [32])

As shown in Fig. 1, there are four levels of organizational barriers to energy-efficiency investments. The investigation [32] labeled the four barrier levels «Base», «Symptom», «Real», and «Hidden». The level «Real barriers» stands mainly for lack in strategic fit of a project.

«Base» barriers concern the lack of knowledge regarding energy efficiency measures. «Symptom» barriers express actually deeper problems: capital might be allocated to other investments; risk is said to be high. «Real» barriers are formed by low or non-existing strategic character of the investment when companies consider energy use neither as a contributor to their competitive advantage nor as a critical resource [32]. Indirect benefits of energy efficiency can increase the strategic relevance; however, they are frequently poorly understood. «Hidden» barriers are various cultural influences which drive organizations and their decision makers to underrate energy-efficiency investments. Authors of the work [32] suggested as a solution to the energy efficiency gap to strongly communicate the strategic relevance of energy efficiency investments. They, however, do not analyze the determinants of companies strategies in more details, which will have an impact upon investment decisions in addition to the necessary precondition of profitability.

Summarizing the existing body of literature on barriers on investment into energy efficiency, so far only few authors identified strategic barriers in addition to profitability barriers. The connection of energy efficiency to the strategic options derived from the prevailing main business strategies, organizational elements, and financial possibilities found in the different stages of the development of companies has not been analyzed in detail yet according to the findings of the literature research. Additional analysis can result in indications, which barriers and corresponding actions are relevant for companies according to their stage of development.

\section{Methods of research}

To achieve the aim of research, general scientific and special research methods are used:

- methods of analysis and synthesis - for a preliminary analysis with the aim of forming a list of main barriers for energy-efficiency implementation at companies;

- methods of decomposition and deduction - to substantiate of critical strategic barriers in the field of investment in energy-efficient solutions.

\section{Research results}

6.1. Research hypothesis. The research hypothesis of this paper is deducted from the following observation. Investment into energy efficiency and renewable energy is not considered a special category of investment but evaluated strategically. It is analyzed integrated with regular investment into equipment and productivity.

Barriers towards the introduction of energy efficiency measures and renewable energy can be explained by the sequence of strategies generally applied in industries resulting from the stages of lifecycles of businesses and products. From this, it can be deducted which supportive political activities are relevant to counteract the gaps of investment into energy efficiency and renewable energy.

6.2. Life cycle of companies. Performance of processes and infrastructure can be described by S-Curves, which are logistic patterns consisting of four stages: Incubation, growth, maturity, and decline (Fig. 2) [33, 34]. The four stages and their key characteristics are described in the following researches [35-37]:

\section{Incubation}

Most production processes start on a small scale. They are subject to frequent modifications and changes in this first phase of the life cycle. Quality is critical because defective products can damage the reputation of the product or even the entire firm. In the incubation stage profits are low because research and development, production and marketing costs are high. Prices can be set high to recover the initial costs quickly, or, kept low to quickly expand the market.

In this stage most of the activity is focused on product design and marketing. An additional focus will be to ensure that the product is easy to manufacture with high quality. The primary interest is to increase production, while complying with safety, labor, and environmental regulations. Investments that are directly related to these aspects will be given the highest priority. Investments related to reduction of expenses are not considered as important at this stage.

From an organizational point of view, the enterprise will be controlled by the owner with little formal systems.

\section{Growth}

During the growth phase, production increases with the demand. While profits are high, it is important to stay ahead of competitors. During growth the challenge is to increase production while maintaining quality and controlling cost. Ideally, capacity is added gradually anticipating demand. In practice this is difficult, as technical facilities can be up-scaled only in discrete steps [38]. The organization will be controlled by functional managers. A controlling system will be established.

\section{Maturity.}

During maturity, sales still increase. Because of increasing competition, prices will lower. The product or service will be adapted to differentiate from competitors. At the same time, cost must be reduced to maintain profits.

As earnings improve, mature companies will generate more cash from their products than they need for reinvestment. The question of whether a company has too much cash, and, if so, how it should return this cash to stock holders becomes relevant at almost every mature company. Management is experienced and stable.

Not all mature companies are large companies. Many small companies reach their growth ceiling quickly and essentially stay small, mature firms [39, 40]. 


\section{Decline}

In the fourth stage of the S-curve, prices fall and sales drop. An appropriate strategy can be to reintroduce the product with a new feature. A refreshed marketing strategy is important to reach current and prospective customers. Consequently, processes will be scaled down and unprofitable products stopped. Investment will be directed towards new products and processes.

Shrinking operating margins are another symptom of this stage. Companies in this stage have few investment opportunities that generate value. These enterprises will have trouble in refinancing the debt, since lenders will demand more stringent terms.

The organization will become mainly production output related. Strong leadership is needed to identify a strategy to sustain [41]

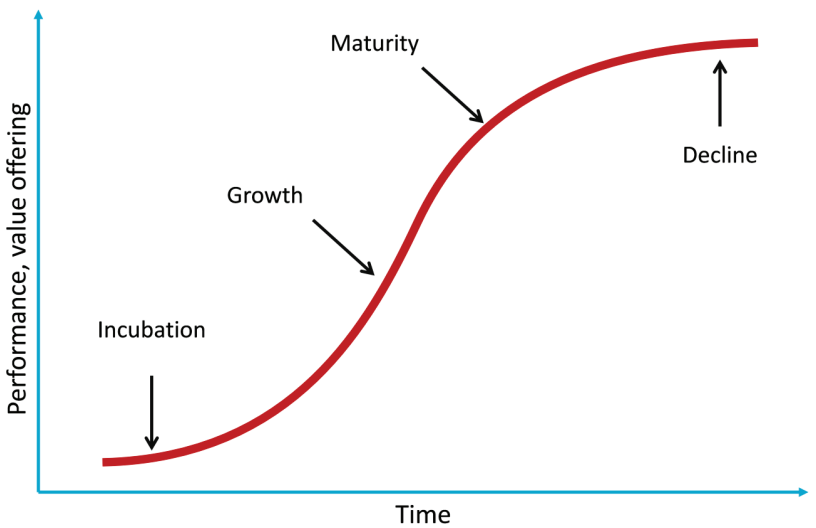

Fig. 2. 5-curve describing the development of performance and value over time (modified from [33])

Table 4 summarizes features of the stages of the life cycle of companies with relevance to the general business strategy, product, characteristics of management, typical cash flow and corresponding barriers for the implementation of energy efficiency measures.

Main difference of the results from Table 4 in comparison to previous research is that it establishes a link between typical parameters of the development stages of an enterprise to the individual barriers for implementing energy efficiency observed in previous research.
6.3. Case study: The measures implemented in the PINE project. As a case study, the energy efficiency measures implemented in 20 companies were analyzed. The companies participated in the PINE project in Austria. The PINE project was supported by the Intelligent Energy Europe program between 2012 and 2015 [43].

The main purpose of the project was promoting energy efficiency in industrial small and medium sized enterprises. The aim was achieving benefits not just for the environment but also as a way to promote both technological and process innovation [44].

The unit operations orientated approach chosen in this program facilitates linking energy consumption to production units and understanding the factors with impact on energy consumption. It is based on an analysis of the company pointing out the most critical areas for its energy efficiency. At the same time it uses models and data acquisition methods which reduce time requirements and disturbances in the firm [45].

The project partnership included 15 organizations from 7 European countries: Austria, Bulgaria, Cyprus, Italy, Romania, Slovakia and Spain. In each country, a scientific partner cooperated with a chamber of commerce or corresponding institution. The chambers of commerce promoted the project, invited and selected companies for the audits and did (part of) the preliminary audits.

Participation in the project was voluntary and free for the companies. They participated following an open call in the region by the chamber of commerce, published in the weekly newsletter which is distributed to all the members of the chamber and announced in several public conferences. Their investment was the involvement of their employees and the implementation of measures.

On average, in the participating enterprises $5 \%$ of energy cost was saved. In general, the companies committed themselves to measures, which pay back in less than three years. For this analysis, the measures implemented in the 20 companies that participated in Austria were analyzed. 87 options were originally identified, out of which 77 were implemented. 10 of the options were dropped after further detailed feasibility analysis. Data were collected for these measures describing the nature of the measure, investment, savings, payback and position of the process and the infrastructure (buildings and basic utilities like boilers) on the S-curve [44].

Technical features of the life cycle stages*

Table 4

\begin{tabular}{|c|c|c|c|c|}
\hline \multirow{2}{*}{ Parameter } & \multicolumn{4}{|c|}{ Life cycle stage } \\
\hline & Incubation & Growth & Maturity & Decline \\
\hline $\begin{array}{l}\text { Recommended } \\
\text { strategy }\end{array}$ & $\begin{array}{c}\text { «Make it work»: Create product } \\
\text { and provide it to the market, deliver } \\
\text { products }\end{array}$ & $\begin{array}{l}\text { «Grow and finance growth»: } \\
\text { Maximize market share }\end{array}$ & $\begin{array}{l}\text { «Minimize cost, consolidate»: } \\
\text { Maximize profits while } \\
\text { defending market share }\end{array}$ & $\begin{array}{l}\text { «Prepare for next generation»: } \\
\text { Reduce expenditure } \\
\text { in general, harvest }\end{array}$ \\
\hline Product & Basic product & $\begin{array}{l}\text { New features, services, } \\
\text { extensions }\end{array}$ & $\begin{array}{l}\text { Diversification of brand and } \\
\text { models, reduce production cost }\end{array}$ & Phase out of weak items \\
\hline $\begin{array}{l}\text { Characteristics } \\
\text { of management }\end{array}$ & $\begin{array}{l}\text { Owner controlled, simple } \\
\text { organization, few employees, } \\
\text { little formal systems }\end{array}$ & $\begin{array}{l}\text { Functional managers, start } \\
\text { of controlling system, delegation }\end{array}$ & $\begin{array}{l}\text { Experienced management, } \\
\text { stability in technology and } \\
\text { market shares }\end{array}$ & $\begin{array}{l}\text { Strong leadership, } \\
\text { output related }\end{array}$ \\
\hline $\begin{array}{l}\text { Characteristics } \\
\text { of cash flow }\end{array}$ & $\begin{array}{l}\text { Focus on generation of cash to } \\
\text { break even and replace wear off of } \\
\text { capital assets }\end{array}$ & Probably high debt/equity rate & $\begin{array}{c}\text { Stagnant margins, lowering } \\
\text { revenue }\end{array}$ & $\begin{array}{l}\text { Dropping margins, few } \\
\text { investment opportunities }\end{array}$ \\
\hline $\begin{array}{l}\text { Corresponding } \\
\text { barrier for } \\
\text { energy efficiency } \\
\text { investment }\end{array}$ & $\begin{array}{l}\text { High priority of production increase, } \\
\text { lack of people responsible and } \\
\text { knowledgeable for energy utilities, } \\
\text { resistance of management to change }\end{array}$ & $\begin{array}{l}\text { Competition for capital, unfavo- } \\
\text { rable to commit resources, } \\
\text { banks perceive energy efficiency } \\
\text { and renewable energy as risky }\end{array}$ & None specific identified & $\begin{array}{l}\text { Technological change, conflic- } \\
\text { ting priorities to convert } \\
\text { mature industry and prepare } \\
\text { new products and processes }\end{array}$ \\
\hline
\end{tabular}

Note: ${ }^{*}$ - modified from [42] 
Table 5 shows the 20 participating companies, their sectors, and products.

Sectors and products of the companies from PINE

Table 5

\begin{tabular}{|c|c|c|}
\hline Company No. & Sector & Product \\
\hline 1 & Metal processing & Engineering \\
\hline 2 & Food processing & Bread and cakes \\
\hline 3 & Food processing & Bread and cakes \\
\hline 4 & Drinks and beverages & Beer \\
\hline 5 & Food processing & Food, oil \\
\hline 6 & Metal processing & Consumer products \\
\hline 7 & Engineering & Supplier of paper industry \\
\hline 8 & Minerals and mining & Minerals \\
\hline 9 & Minerals and mining & Minerals \\
\hline 10 & Minerals and mining & Minerals \\
\hline 11 & Metal processing & Electrodes \\
\hline 12 & Food processing & Edible oil \\
\hline 13 & Metal processing & Products from wire \\
\hline 14 & Engineering & 5upplier of metal processing \\
\hline 15 & Food processing & Bread \\
\hline 16 & Food processing & Flour \\
\hline 17 & Engineering & 5upplier of metal products \\
\hline 18 & Minerals and mining & Refractories \\
\hline 19 & Wood processing & Furniture \\
\hline 20 & Food processing & Chocolate \\
\hline & & \\
\hline
\end{tabular}

The assessment of lifecycle stage, the products and processes and the infrastructure was done out of a discussion of the researchers with company representatives, without a quantitative evaluation of company data and market data.

For the identification of the corresponding life cycle phases for the companies in the case studies, was used, condensing the features presented in Table 6 .

The measures that were implemented within the PINE project in Austria [44] were analyzed individually (Table 7).

Table 7 shows that about $70 \%$ of total energy savings were connected to heating. Heat recovery from production processes and building refurbishment have a share of about $60 \%$ of the options. In buildings, investment costs are rather high resulting in longer payback periods.

Other relevant improvement measures are the isolation of the heat distribution system and improved control of the heating and boiler system.

About $50 \%$ of the identified electricity savings are because of installation of frequency-controlled drives, compressed air system modernization or improving illumination.

These areas are already today addressed in many brochures and information materials provided by potential suppliers, the chambers, energy agencies and other public institutions.

Technical features of the life cycle stages for the case studies

\begin{tabular}{|c|c|c|c|}
\hline Phase & Incubation & Growth & Maturity \\
\hline Age of process or equipment & $0-2$ years & 2 to 7 years & 7 to 10 years \\
\hline Age of infrastructure & $0-5$ years & 5 to 10 years & 10 to 20 years \\
\hline Relevant business strategy & Proof of technology & Increase market share & Reduce cost \\
\hline Investment volume & High & High, product related & Low, process related \\
\hline
\end{tabular}

Measures identified in companies from PINE

Table 7

\begin{tabular}{|c|l|c|c|c|c|}
\hline Measure No. & \multicolumn{1}{|c|}{ Measure } & Payback (years) & Implemented & Process phase & Building phase \\
\hline 1 & \multicolumn{1}{|c|}{2} & 3 & 4 & 5 & $\mathrm{G}$ \\
\hline 1 & Building refurbishment (exterior walls, windows, top floor ceiling) & 20.00 & $\mathrm{Y}$ & $\mathrm{M}$ & $\mathrm{D}$ \\
\hline 2 & Installation of heat recovery at compressors & 3.00 & $\mathrm{Y}$ & $\mathrm{M}$ & $\mathrm{D}$ \\
\hline 3 & Identification of parasitic consumers and reduction of base load by 25 \% & 2.00 & $\mathrm{Y}$ & $\mathrm{M}$ & $\mathrm{D}$ \\
\hline 4 & Heat recovery and maintenance at/of chillers & 4.00 & $\mathrm{~N}$ & $\mathrm{D}$ & $\mathrm{D}$ \\
\hline 5 & $\begin{array}{l}\text { Isolation of the pipes and connections in the bailer room and the produc- } \\
\text { tion area }\end{array}$ & 1.00 & $\mathrm{Y}$ & $\mathrm{D}$ & $\mathrm{D}$ \\
\hline 6 & Control of steaming to reduce heat losses & 1.00 & $\mathrm{Y}$ & $\mathrm{D}$ & $\mathrm{D}$ \\
\hline 7 & Installation of heat recovery systems at ovens & 4.00 & $\mathrm{~N}$ & $\mathrm{D}$ & $\mathrm{D}$ \\
\hline 8 & Exchange of existing lighting & 24.00 & $\mathrm{Y}$ & $\mathrm{M}$ & $\mathrm{D}$ \\
\hline 9 & Heat recovery system at cooling plant & 4.00 & $\mathrm{Y}$ & $\mathrm{M}$ & $\mathrm{D}$ \\
\hline 10 & Heat recovery (refurbishment) at ovens, isolation & 1.00 & $\mathrm{Y}$ & $\mathrm{M}$ & $\mathrm{D}$ \\
\hline 11 & Introduction of a simple energy controlling and monitoring system & 1.00 & $\mathrm{Y}$ & $\mathrm{M}$ & $\mathrm{D}$ \\
\hline 12 & Changing the whole system by making use of district heating instead of oil & 20.00 & $\mathrm{Y}$ & $\mathrm{M}$ & $\mathrm{D}$ \\
\hline 13 & Exchanging lighting - installation of LED & 4.00 & $\mathrm{Y}$ & $\mathrm{M}$ & $\mathrm{D}$ \\
\hline 14 & Keduction of compressed air leakages & 1.00 & $\mathrm{Y}$ & $\mathrm{M}$ & $\mathrm{D}$ \\
\hline 15 & Exchanging the existing lighting by more efficient installations (LED) & 5.00 & $\mathrm{Y}$ & $\mathrm{G}$ & $\mathrm{G}$ \\
\hline 16 & Keduction of air flow at one of the production processes & 2.00 & $\mathrm{Y}$ & $\mathrm{G}$ & $\mathrm{G}$ \\
\hline 17 & $\begin{array}{l}\text { Detailed analysis of the cooling demand, reduction of air exchange and } \\
\text { internal heat sources }\end{array}$ & 0.31 & $\mathrm{Y}$ & $\mathrm{G}$ & $\mathrm{G}$ \\
\hline
\end{tabular}




\begin{tabular}{|c|c|c|c|c|c|}
\hline 1 & 2 & 3 & 4 & 5 & 6 \\
\hline 18 & Reduction of air flow in drying & 2.00 & $\bar{Y}$ & $\bar{G}$ & $\bar{G}$ \\
\hline 19 & Exchanging T8-lights to LED & 8.00 & $\mathrm{Y}$ & G & G \\
\hline 20 & Sealing of compressed air leakages & 1.00 & $\mathrm{Y}$ & G & G \\
\hline 21 & Belt replacement at the motors of the polishing drums & 2.00 & $\mathrm{~N}$ & G & G \\
\hline 22 & Installation of a photovoltaic plant & 8.00 & Y & G & G \\
\hline 23 & Exchanging the existing lighting to more efficient installations (LED) & 3.00 & Y & M & M \\
\hline 24 & Installation of heat recovery systems at ovens & 2.00 & $\mathrm{Y}$ & M & M \\
\hline 25 & Installation of a simple energy controlling and monitoring system & 2.00 & Y & M & $\mathrm{M}$ \\
\hline 26 & Exchanging T8-lights to LED & 39.00 & $\mathrm{Y}$ & $\mathrm{M}$ & M \\
\hline 27 & Checkup of the compressed air system and reduction of leakages & 2.00 & Y & M & M \\
\hline 28 & Using speed control for pumps and fans & 2.00 & Y & M & M \\
\hline 29 & Using smaller motors and speed control & 2.00 & $\mathrm{Y}$ & $\mathrm{M}$ & M \\
\hline 30 & Maintenance of the chillers and making use of the free cooling function & 2.00 & $\mathrm{Y}$ & M & M \\
\hline 31 & Isolation of the pipes and connections & 2.00 & Y & M & M \\
\hline 32 & Exchanging T8-lights to LED & 8.00 & Y & M & M \\
\hline 33 & Regular control of the compressed air system and reduction of leakages & 2.00 & Y & M & M \\
\hline 34 & Using smaller motors and speed control & 2.00 & Y & M & M \\
\hline 35 & Maintenance, regulation, and isolation of the pipes & 2.00 & $\mathrm{Y}$ & M & M \\
\hline 36 & Exchanging sodium discharge lamps by LEDs & 10.00 & Y & M & $\mathrm{M}$ \\
\hline 37 & Preheating the combustion air & 2.00 & $\mathrm{Y}$ & $\mathrm{M}$ & M \\
\hline 38 & 2 pressure levels in compressed air system, speed control, leakage control & 2.00 & Y & M & M \\
\hline 39 & Using the waste heat of the compressors for a regional district heating system & 1.00 & $\mathrm{Y}$ & $\mathrm{M}$ & M \\
\hline 40 & Reducing heat losses by using a lid at the melting oven & 1.00 & Y & M & M \\
\hline 41 & Full utilization of the production capacity & 2.00 & $\mathrm{Y}$ & M & M \\
\hline 42 & Preheating and drying of the metals by product waste heat & 1.00 & $\mathrm{Y}$ & $\mathrm{M}$ & M \\
\hline 43 & Organizational actions to reduce the nitrogen demand & 1.00 & $\mathrm{Y}$ & M & $\mathrm{M}$ \\
\hline 44 & Exchanging existing T8 lighting to LED & 20.00 & $\mathrm{~N}$ & M & D \\
\hline 45 & Variable speed contral for pumps & 23.00 & Y & M & $\mathrm{D}$ \\
\hline 46 & Reduction of the air flow at one process by organizational measures & 2.00 & $\mathrm{Y}$ & $\mathrm{M}$ & $\mathrm{D}$ \\
\hline 47 & Heat recovery at one of the production processes & 19.00 & $\mathrm{Y}$ & $\mathrm{M}$ & $\mathrm{D}$ \\
\hline 48 & Improved control of the heating system & 1.08 & $\mathrm{Y}$ & M & D \\
\hline 49 & Isolation of the hot water pipes & 1.00 & $\mathrm{Y}$ & M & D \\
\hline 50 & Monitoring of the natural gas demand for painting and warm water & 2.00 & $\mathrm{Y}$ & $\mathrm{M}$ & $\mathrm{D}$ \\
\hline 51 & Using daylight & 0.50 & $\mathrm{Y}$ & $\mathrm{M}$ & $\mathrm{D}$ \\
\hline 52 & Reduction of the compressed air pressure and preventing leakages & 1.00 & $\mathrm{Y}$ & $\mathrm{M}$ & $\mathrm{D}$ \\
\hline 53 & Exchanging v-belts to direct drives & 2.00 & $\mathrm{Y}$ & M & $\mathrm{D}$ \\
\hline 54 & Refurbishment of the hydro-electric power station & 20.00 & $\mathrm{Y}$ & $\mathrm{M}$ & D \\
\hline 55 & Isolation of the upper ceiling to reduce heat losses & 7.00 & $\mathrm{Y}$ & M & D \\
\hline 56 & Exchanging T8-lights to LED & 8.00 & $\mathrm{~N}$ & $\mathrm{D}$ & D \\
\hline 57 & Installation of heat recovery systems at the chillers & 12.00 & $\mathrm{Y}$ & $\mathrm{D}$ & $\mathrm{D}$ \\
\hline 58 & Heat recovery system (to preheat the combustion air) of ovens & 10.00 & $\mathrm{Y}$ & $\mathrm{D}$ & $\mathrm{D}$ \\
\hline 59 & Installation of an absorption refrigerator & 5.00 & $\mathrm{~N}$ & $\mathrm{D}$ & $\mathrm{D}$ \\
\hline 60 & Installation of energy efficient motors & 10.00 & $\mathrm{~N}$ & $\mathrm{D}$ & $\mathrm{D}$ \\
\hline 61 & Reduction of the air volumes for the roasting process & 2.00 & $\mathrm{Y}$ & $\mathrm{D}$ & $\mathrm{D}$ \\
\hline 62 & Exchanging T8-lights to LED & 6.00 & $\mathrm{Y}$ & $\mathrm{D}$ & $\mathrm{D}$ \\
\hline 63 & Sealing of leakages of the compressed air system & 2.00 & $\mathrm{Y}$ & $\mathrm{D}$ & $\mathrm{D}$ \\
\hline 64 & Exchange of sodium discharge lamps to LEDs & 9.00 & $\mathrm{Y}$ & M & D \\
\hline 65 & Isolation of the ovens and renew the seals of the holding furnaces & 1.00 & $\mathrm{Y}$ & $\mathrm{M}$ & $\mathrm{D}$ \\
\hline 66 & Installation of a simple energy controlling and monitoring system & 2.00 & $\mathrm{~N}$ & $\mathrm{M}$ & $\mathrm{D}$ \\
\hline 67 & Isolation of the pipes and connections in the boiler room & 2.00 & Y & M & D \\
\hline 68 & Improvement of the separation efficiency of the cyclone & 7.00 & Y & M & $\mathrm{D}$ \\
\hline 69 & Installation of variable speed drives for fans & 7.00 & $\mathrm{Y}$ & M & $\mathrm{D}$ \\
\hline 70 & Installation of new compressors & 7.00 & $\mathrm{Y}$ & $\mathrm{M}$ & $\mathrm{D}$ \\
\hline 71 & Installation of a heat recovery system at the furnace & 7.00 & Y & $\mathrm{M}$ & $\mathrm{D}$ \\
\hline 72 & Installation of a PV plant & 8.00 & $\mathrm{Y}$ & M & $\mathrm{M}$ \\
\hline
\end{tabular}


Continuation of Table 7

\begin{tabular}{|c|l|c|c|c|c|}
\hline 1 & \multicolumn{1}{|c|}{ 2 } & 3 & 4 & 5 & 6 \\
\hline 73 & Exchange of the existing T8 lighting to LEDs & 7.00 & $\mathrm{Y}$ & $\mathrm{M}$ & $\mathrm{M}$ \\
\hline 74 & Dptimization of the ventilation system & 7.00 & $\mathrm{Y}$ & $\mathrm{M}$ & $\mathrm{M}$ \\
\hline 75 & Turning off the mixer motors at the storage tanks & 0.50 & $\mathrm{Y}$ & $\mathrm{G}$ & $\mathrm{G}$ \\
\hline 76 & Reduction of the operation time of the mills & 2.00 & $\mathrm{Y}$ & $\mathrm{G}$ & $\mathrm{G}$ \\
\hline 77 & Reduction of the standby time at the packaging section & 2.00 & $\mathrm{Y}$ & $\mathrm{G}$ & $\mathrm{G}$ \\
\hline 78 & Reduction of idling losses at filling machine & 2.00 & $\mathrm{Y}$ & $\mathrm{g}$ & $\mathrm{G}$ \\
\hline 79 & Check of parasitic consumers in the production area & 2.00 & $\mathrm{Y}$ & $\mathrm{G}$ & $\mathrm{G}$ \\
\hline 80 & Increase of production capacity & 7.00 & $\mathrm{~N}$ & $\mathrm{G}$ & $\mathrm{G}$ \\
\hline 81 & Reduction of water consumption at the washing plant & 2.00 & $\mathrm{Y}$ & $\mathrm{G}$ & $\mathrm{G}$ \\
\hline 82 & Control of parasitic consumers in the offices & 2.00 & $\mathrm{Y}$ & $\mathrm{G}$ & $\mathrm{G}$ \\
\hline 83 & Installation of a new compressor for the heating system & 10.00 & $\mathrm{Y}$ & $\mathrm{G}$ & $\mathrm{G}$ \\
\hline 84 & $\begin{array}{l}\text { Installation of double-glazed windows in the production area to reduce } \\
\text { energy demand for air conditioning }\end{array}$ & 3.00 & $\mathrm{Y}$ & $\mathrm{G}$ & $\mathrm{G}$ \\
\hline 85 & Optimization of control parameters of the heating system & 2.00 & $\mathrm{Y}$ & $\mathrm{G}$ & $\mathrm{G}$ \\
\hline 86 & Use of organic waste as fertilizer & 10.00 & $\mathrm{~N}$ & $\mathrm{G}$ & $\mathrm{G}$ \\
\hline 87 & Installation of power factor correction & 0.50 & $\mathrm{Y}$ & $\mathrm{G}$ & $\mathrm{G}$ \\
\hline
\end{tabular}

Note: Y - yes, N - no, M - maturity; D - decline; G - growth

Authors of the work [32] introduced the concept of a «gap» between payback and actual implementation, which was attributed to the strategic relevance of the investment into energy efficiency, without analyzing this «strategic relevance» in more detail. This is the starting point for this paper: an analysis has been done, which generic strategies and properties of companies exist at which development stage of an enterprise (S-curves of enterprise development) and the observed implementation of measures from the case studies related to the stage of an enterprise. So, the scientific novelty of this article is that with the help of S-curve of enterprise development analysis, the observed gap of beneficial benefit of some energy efficiency investment and actual implementation was closed. It provides a starting point for defining a targeted approach to promote energy efficiency, or resource efficiency. This exploratory research analyzed the energy efficiency measures implemented by 20 Austrian companies within the PINE project in 2015. The participating companies were classified according to four stages as they are used in literature describing the maturity of the enterprises. In total 77 measures were implemented. 10 measures which were suggested by the consulting team were not implemented.

The response of the small and medium sized enterprises towards adopting energy efficiency measures was positive. A large share of energy is used for support processes such as lighting, heating and cooling, which are similar across the sectors. This opens up possibilities for standardized solutions, which can be shared effectively.

From Tables 8, 9 it can be taken that 46 measures were implemented in companies in which processes or buildings were rated as «mature». 18 measures were identified in companies which were rated as «growing». 13 were identified in companies which were rated as «declining» and none in a company which was classified as «incubating». Implementation was not always directly linked to short payback times. The share of measures with short payback (less than two years) was largest during the «growth» phase $(69 \%)$, followed by the measures implemented in the «mature» phase $(63 \%)$ and lowest in the «decline» phase $(54 \%)$. The latter measures were mostly building renovation measures to upgrade old buildings (windows, lights, ceilings). This observation goes together with the business strategies described in Table 4.

Tahle 8

Analysis of the implemented energy efficiency and renewable energy measures from PINE in processes

\begin{tabular}{|c|c|c|c|c|}
\hline Phase & $\begin{array}{c}\text { Implemented } \\
\text { measures }\end{array}$ & $\begin{array}{c}\text { Payback } \\
<2 \text { years }\end{array}$ & $\begin{array}{c}\text { Payback } \\
\text { 2-6 years }\end{array}$ & $\begin{array}{c}\text { Payback } \\
>6 \text { years }\end{array}$ \\
\hline Incubation & 0 & 0 & 0 & 0 \\
\hline Growth & 13 & 11 & 0 & 2 \\
\hline Maturity & 36 & 25 & 3 & 8 \\
\hline Decline & 7 & 4 & 1 & 2 \\
\hline
\end{tabular}

Table 9

Analysis of the implemented energy efficiency and renewable energy measures from PINE in buildings

\begin{tabular}{|c|c|c|c|c|}
\hline Phase & $\begin{array}{c}\text { Implemented } \\
\text { measures }\end{array}$ & $\begin{array}{c}\text { Payback } \\
<2 \text { years }\end{array}$ & $\begin{array}{c}\text { Payback } \\
\text { 2-6 years }\end{array}$ & $\begin{array}{c}\text { Payback } \\
>6 \text { years }\end{array}$ \\
\hline Incubation & 0 & 0 & 0 & 0 \\
\hline Growth & 5 & 0 & 3 & 2 \\
\hline Maturity & 10 & 4 & 0 & 6 \\
\hline Decline & 6 & 2 & 0 & 4 \\
\hline
\end{tabular}

Energy efficiency measures and renewable energy are applied in these companies with different motivation:

- In the incubation phase. No company in the incubation phase was participating. In this phase, when investment into new equipment is done, the focus can be on energy efficient equipment. From the interviews conducted with management of the participating companies, the authors conclude that if energy efficient equipment is known at the incubation stage and economical, it might well be implemented.

- In the growth phase. During the growth phase, in the case study companies, implementation of energy efficiency and renewable energy measures was of lower priority than production growth. Measures with a quick payback, however, had a good chance to be implemented. 
- In the maturity phase. During maturity, in the case study companies there was a general focus on implementing measures for cost reduction. This includes energy efficiency measures to improve processes, and also infrastructure.

- In decline. During decline, in the case study companies buildings and other infrastructure were upgraded to prepare for new processes or products and to enlarge the lifetime of buildings, reflecting also in investment with longer payback times.

These observations fit the priority strategies for the four stages of enterprise development (Table 10):

1. During the incubation phase, the strategic focus is on product development and quality. During this phase, there is no explicit priority on energy efficiency. No company classified in this stage participated in the PINE project. 10 relates the generic strategy of the stage to energy efficiency and the use of renewable energy.

2. During the growth phase, the main strategic focus is on sustaining growth and growing market share. 3 companies and 3 buildings of companies of the PINE project were classified as «growing». In these, 18 measures were implemented. In this category the share of measures with a payback of less than two years was the largest one. 0 relates the generic strategy of the stage to energy efficiency and the use of renewable energy.

3. During the maturity phase, the strategic focus is on consolidation and cost minimization. 14 companies and 7 buildings were classified as «mature». 46 measures were implemented in companies or buildings of this category. In this phase there was the biggest share of process related measures. The share of measures with a payback time higher than two years was slightly higher than in «growth». 10 relates the generic strategy of the stage to energy efficiency and the use of renewable energy.

4. During the decline phase, the strategic focus is on the reduction of expenditure in general. 3 companies and 10 buildings were classified in this category. 13 measures were implemented in companies or buildings of this category. The share of measures with a payback time higher than two years is higher than in «growth» and «maturity». In this category, more than $50 \%$ of measures are implemented in buildings. 0 relates the generic strategy of the stage to energy efficiency and the use of renewable energy.

Energy efficiency strategies for different phases of enterprise

\begin{tabular}{|c|c|c|}
\hline $\begin{array}{c}\text { Phase of the } \\
\text { enterprise }\end{array}$ & Business strategy & $\begin{array}{c}\text { Corresponding strategy } \\
\text { for Energy efficiency }\end{array}$ \\
\hline Incubation & $\begin{array}{c}\text { "Make it work»: Create the } \\
\text { product and provide it to the } \\
\text { market, deliver products }\end{array}$ & $\begin{array}{c}\text { Energy efficiency is not } \\
\text { a priority at this stage }\end{array}$ \\
\hline Growth & $\begin{array}{c}\text { "Grow and finance growth»: } \\
\text { Maximize market share }\end{array}$ & $\begin{array}{c}\text { Implement very profitable } \\
\text { energy efficiency measures } \\
\text { to support the efficiency of } \\
\text { processes }\end{array}$ \\
\hline Maturity & $\begin{array}{c}\text { Manimize cost, consolidate»: } \\
\text { Mefending market share }\end{array}$ & $\begin{array}{c}\text { Implement energy efficiency } \\
\text { measures to systematically } \\
\text { reduce operational cost }\end{array}$ \\
\hline Decline & $\begin{array}{c}\text { «Prepare for next generation»: } \\
\text { Reduce expenditure in } \\
\text { general, harvest }\end{array}$ & $\begin{array}{c}\text { Implement energy efficiency } \\
\text { measures to improve the } \\
\text { infrastructure for the future }\end{array}$ \\
\hline
\end{tabular}

These results origin from a group of 20 companies who volunteered for energy audits out of a general invitation to all the enterprises in the Austrian federal state of Styria. They participated following an open call in the region by the chamber of commerce, published in the weekly newsletter which is distributed to all the members of the chamber and announced in several public conferences. It can be concluded that the volunteering companies were already sensitive towards energy efficiency and renewable energy. As consequence, however, there is no equal distribution of life cycle stage of processes and infrastructure. The results probably reflect the practice of companies already interested into energy efficiency and renewable energy.

The aim of research was to contribute towards overcoming the apparent gap in investment in energy efficiency evaluating case studies from 20 companies in Austria.

To achieve this aim, this paper has summarized barriers to the implementation of energy efficiency and renewable energy from relevant literature. At present, energy prices are not likely to accelerate energy efficiency investment at the required rate. In Austria, the price of natural gas has significantly decreased over the period of 2013 to 2018 . Prices for equipment and construction have increased. Increasing investment cost together with decreasing gas prices increase the payback time and reduce the motivation for investment into energy efficiency and renewable energy in industries. There are «multiple benefits» mostly on a macroeconomic level, but these are beyond the control and immediate priorities of production companies, unless they match requirements from clients. At the same time investments in industries in Austria generally have decreased.

This paper has identified a novel approach to organizing the barriers to the implementation of energy efficiency measures along the stages of the lifecycle of processes and buildings suggesting a detailed interpretation of aspects of the implementation gap for energy efficiency measures identified in [32]. The connection of implementation of energy efficiency measures and renewable energy to company life cycle stages was tested on measures which were implemented as a result of 20 energy audits in enterprises in Austria. Table 11 summarizes the conclusions from this research.

Table 11

Conclusions from the cases

\begin{tabular}{|c|c|c|c|c|}
\hline \multirow{2}{*}{ Parameter } & \multicolumn{4}{|c|}{ Phase } \\
\hline & Incubation & Growth & Maturity & Decline \\
\hline $\begin{array}{l}\text { Opportunity } \\
\text { for energy } \\
\text { efficiency and } \\
\text { renewable } \\
\text { energy }\end{array}$ & $\begin{array}{l}\text { Basically high } \\
\text { (however, because } \\
\text { of energy con- } \\
\text { sumption is still } \\
\text { low, so priority is } \\
\text { low too) }\end{array}$ & Moderate & High & $\begin{array}{c}\text { Generally } \\
\text { low }\end{array}$ \\
\hline $\begin{array}{l}\text { Focus of the } \\
\text { investments }\end{array}$ & $\begin{array}{c}\text { Focus is on } \\
\text { energy efficiency } \\
\text { and renewable } \\
\text { energy measures } \\
\text { in developing } \\
\text { processes and } \\
\text { equipment }\end{array}$ & $\begin{array}{c}\text { Focus on } \\
\text { process } \\
\text { and product } \\
\text { optimiza- } \\
\text { tion }\end{array}$ & $\begin{array}{c}\text { Focus on } \\
\text { (short } \\
\text { term) cost } \\
\text { reduction }\end{array}$ & $\begin{array}{c}\text { Focus on } \\
\text { upgrading } \\
\text { infrastruc- } \\
\text { ture and } \\
\text { preparing } \\
\text { for } \\
\text { a change }\end{array}$ \\
\hline
\end{tabular}

Out of this research, a business-oriented strategy to increase energy efficiency level at different types of companies is developed. This model proposes a new way of organizing the barriers to the implementation of energy efficiency 
measures along the stages of the lifecycle of processes and buildings. From the results of this exploratory research, in congruence with the findings of [32] it is deducted that a match of energy efficiency projects with company strategy is relevant. The business strategies derived from the organizational life cycle model can give hints in which stages investment into which type of energy efficiency measures will be preferred: cost saving measures during maturity and measures preparing the enterprise for transition by improving infrastructure in the phase of decline.

Companies with new products and processes can benefit by including energy efficiency and renewable energy into the design of the processes and equipment. However, in this stage, cost needs to be considered carefully, as probably financial capital will be limited, and energy efficiency rarely will be dealt with independently from general business. Therefore, proven energy efficient options should be carefully integrated with process technology. If the measures are introduced early at the design stage, the cost is more economical, as there is no cost for demolishing, and modifying existing equipment as in the case of retrofitting energy efficient options. Especially at this stage, business is centered on the owner whose priorities are on product, production, and quality.

Growing companies provide a moderate opportunity. Their strategy is focused on optimizing their product and production processes, not necessarily on cost reduction. At the same time there is little formal management structure and specialized personnel which is focusing on energy efficiency.

In mature companies the business strategy is on cost reduction. Companies with mature processes might choose energy efficiency measures which pay back in less than two or three years. The required payback time results from the fact that the remaining potential time of use of the process is limited. The investment should pay back before the main process becomes obsolete and renders connected equipment valueless. In this phase the implementation of good housekeeping measures (optimization of control, optimization of process parameters, optimized works planning) has priority. A formal organization supports a more systematic approach to energy efficiency at this development stage.

Investment with a long payback time still might be implemented, if the remaining useful life of equipment justifies the investment. This is especially true for the buildings which in Austrian small and medium enterprises (SMEs) participating in the PINE project represent a significant share of overall electricity and heat consumption. In the companies of the PINE project quite a few enterprises exchanged their lights to LEDs, sometimes remodeling the entire lighting system and upgraded walls and windows.

A recent International Energy Agency report confirms the critical importance of policies in driving investment in renewable energy [46]. Stable long-term policies might influence company strategies. A political strategy should target three levels of intervention concluding from this research: - a focus on companies with new products and processes during the incubation phase when installing new process equipment;

- a focus on mature companies which are looking for opportunities for cost reduction and have the capital to invest;

- a focus on companies in decline which are investing in changing products and processes.
Companies with products and processes in the incubation phase require energy efficiency measures which are already integrated into the new equipment. The focus of political support should be on the development of technologies for which a pronounced learning curve can be expected. This includes the development of standardized designs, simplified technologies, and use of cheaper materials. A strong learning curve can reduce uncertainty and make investment decisions less risky. Therefore, targeted support of suppliers of key energy efficient process components is paramount. This should target innovative energy efficient products and energy efficient process equipment as a cost-efficient option when new process equipment is installed, or new buildings are erected. Targeted grants can stimulate research on energy efficient equipment and support demonstration projects to show case energy efficient solutions.

Relevant information could be spread, for example, in incubators targeting start-up companies. Also, existing information channels, for example, via the chambers can be used to disseminate information on available options.

Maturing processes require simple energy efficiency upgrades which reduce cost, and do not interfere with the productivity of the main technology. Examples include optimizing process parameters, upgrade of control equipment, retrofitting variable speed drives on fans and pumps, etc. Ideally, these solutions should be standardized and modular to reduce planning and transaction cost.

Companies in decline with old infrastructure are more likely to invest into buildings, if these can be used for changed processes and new products. Therefore, for these cases, there should be financial support to lower investment barriers.

The findings suggest also a targeted awareness raising approach towards companies accounting for their varying motivation. Upfront information and support on energy efficiency and renewable energy is mostly needed for incubating companies. Information about simple measures with short payback times should be targeted mostly at growing enterprises. Information on building renovation and long-term measures according to the findings are more targeted towards mature companies and companies renovating their infrastructure. The identified strategic options can also be extrapolated to resource efficiency in more general terms, including material efficiency, use of water, and chemicals. These aspects all equally production related, because of the urgency of climate change it has become customary to address energy with a priority and focus. In principle, it is possible to think that the observations regarding profitability and strategic relevance also apply to waste reduction, management of chemicals, and water use, also to the aspects of material selection, product design, recycling, and circular economy. This is why it has been defined the title «Exploratory research...». Time permitting, one could collect case studies related to the broader field of resource efficiency and use the criteria proposed in this paper for a classification.

\section{SWOT analysis of research results}

Strengths. The strengths lie in the fact that the developed business and political strategies for energy efficiency implementation allow to assess the ability of an enterprise to develop successfully in any stage of its life cycle. 
Even enterprises with incubation stage could increase their future profitability, using provided in the investigation strategies. It needs to be focused, that results have been achieved from the PINE project, which were implemented in Austria. 20 enterprises from different economic sectors and with different stage of life cycle shared their results, which allows for their effective redistribution.

Weaknesses. The main weakness of this method is the difficulty of comparison of different enterprises. Enterprises with the same raw materials inputs and outputs could have different technological cycle. Because of this, payback periods could be different.

Opportunities. The strategies are formed on the basis of the 20 energy audits for enterprises from different economic sectors that makes it possible in the future to replicate this experience for Ukrainian enterprises.

Threats. The main threat to the use of the political strategies, which were developed in the investigation, is unstable political situation in Ukraine.

\section{Conclusions}

1. This investigation shows that there are such main categories of barriers:

- «Base» barriers concern the lack of knowledge regarding energy efficiency measures.

- «Symptom» barriers express deeper problems: capital might be allocated to other investments; risk is said to be high.

- «Real» barriers are formed by the real obstacle to energy-efficiency investments, which is low or non-existing strategic character of the investment for companies.

2. Business-oriented strategies for raising energy efficiency for different types of companies have been developed: - at the design stage, companies are recommended to include energy efficiency and renewable energy measures in developing processes and equipment. In this case, losses are even justified, as priorities are not on efficiency, but on product quality and speed to market; - for companies that are in the stage of growth, the strategy should be aimed at optimizing production processes, and not necessarily in reducing costs. Formal energy management and trained personnel to identify energy efficiency improvement is not present in such companies; - for mature companies, the recommended strategy is in reducing avoidable costs for energy resources. It is identified that the implementation of energy efficiency measures with a pay-back period of $2-3$ years is common in this stage. The payback period is justified by the residual potential use time of the process. That is, an investment should pay off before the main process becomes obsolete. At this stage, the priority is the introduction of the following measures: optimization of management, optimization of process parameters, optimization of work planning. For mature companies, the systemic approach to energy efficiency is significant;

- for companies in decline, strategic attention should be given to the implementation of strategic measures for re-engineering the company as a whole or for individual technological processes. At the same time, the payback period might not be the main criterion for investment. 3. The following policy strategies were proposed: - state funding directed at the prevailing strategies at the various stages of the company's life cycle;
- consistent support for low risk investment measures; - support to targeted research to reduce energy efficiency investment costs to use economy of scale and to reduce transaction costs;

- support research and development of innovative energy efficient processes and infrastructure to reduce the risks arising from investment in the early stages of the technical life cycle.

\section{References}

1. World Energy Investment 2017. International Energy Agency. Paris, 2017. 191 p. doi: http://doi.org/10.1787/9789264277854-en

2. Investment in energy fell again in 2017 , raising fresh concerns about security and climate change. CNBC LLC. URL: https:// www.cnbc.com/2018/07/16/investment-in-energy-fell-again-in2017-international-energy-agency.html

3. Preliminary assessment of waste heat potential in major European industries / Panayiotou G. P., Bianchi G., Georgiou G., Aresti L., Argyrou M., Agathokleous R. et. al. // Energy Procedia. 2017. Vol. 123. P. 335-345. doi: http://doi.org/10.1016/ j.egypro.2017.07.263

4. Capturing the multiple effects of energy efficiency / International Energy Agency. Paris, 2014. 232 p. doi: http://doi.org/ 10.1787/9789264220720-en

5. Renewable Energy for Industry - From green energy to green materials and fuels / International Energy Agency. Paris, 2017. 72 p.

6. Energy Efficiency as a Low-Cost Resource for Achieving Carbon Emissions Reductions / ICF International. Washington, 2009. 86 p. doi: http://doi.org/10.2172/1219670

7. Barriers to Industrial Energy Efficiency Report to Congress June 2015 / Department of Energy. Washington, 2015. 28 p.

8. Tailoring cross-sectional energy-efficiency measures to target groups in industry / Wohlfarth K., Eichhammer W., Schlomann B., Worrell E. // Energy Efficiency. 2018. Vol. 11, Issue 5. P. 1265-1279. doi: http://doi.org/10.1007/s12053-018-9619-7

9. Walsh C., Thornley P. Barriers to improving energy efficiency within the process industries with a focus on low grade heat utilization // Journal of Cleaner Production. 2012. Vol. 23, Issue 1. P. 138-46. doi: http://doi.org/10.1016/j.jclepro.2011.10.038

10. Lefley F. The payback method of investment appraisal: A review and synthesis // International Journal of Production Economics. 1996. Vol. 44, Issue 3. P. 207-224. doi: http:// doi.org/10.1016/0925-5273(96)00022-9

11. Mayes Tr. FIN 3300: Chapter 9. URL: https://slideplayer com/slide/3824145/

12. Solnordal M. T., Foss L. Closing the Energy Efficiency Gap A Systematic Review of Empirical Articles on Drivers to Energy Efficiency in Manufacturing Firms Energies // Energies. 2018. Vol. 11, Issue 3. P. 518. doi: http://doi.org/10.3390/en11030518

13. Anderson S. T., Newell R. G. Information programs for technology adoption: the case of energy-efficiency audits // Resource and Energy Economics. 2004. Vol. 26, Issue 1. P. 27-50. doi: http://doi.org/10.1016/j.reseneeco.2003.07.001

14. Examples of Appropriate Payback periods. Lean Manufacture URL: http://www.leanmanufacture.net/kpi/paybackperiod.aspx

15. Gallo A. A refresher on payback method // Harvard Business Review. 2016. URL: https://hbr.org/2016/04/a-refresher-onpayback-method

16. Marktentwicklungen von Energieeffizienzmaßnahmen, Energieaudits und anderen Energiedienstleistungen gemäß $§ 24$ Abs. 2 Z 8 EEffG. Berichtsjahr 2017. Monitoringstelle Energieeffizienz. Wien, 2017. 82 p.

17. Prices for gas, steel, copper // Eurostat. URL: http://ec.europa.eu/ eurostat/web/energy/data/main-tables

18. Leoni T. Entwicklung und Struktur der Arbeitskosten und der Lohnstückkosten 2000 bis 2015 . Ein kommentierter Datenüberblick/Österreichisches Institut für Wirtschaftsforschung. Wien, 2017. 66 p.

19. Van Soest D., Bulte E. Does the energy-efficiency paradox exist? Technological progress and uncertainty // Environmental and Resource Economics. 2001. Vol. 18, Issue 1. P. 101-112. doi: http://doi.org/10.1023/a:1011112406964 
20. Soepardi A., Thollander P. Analysis of Relationships among Organizational Barriers to Energy Efficiency Improvement: A Case Study in Indonesia's Steel Industry // Sustainability. 2018. Vol. 10, Issue 1. P. 216. doi: http://doi.org/10.3390/ su10010216

21. Value added barometer (Wertschöpfungsbarometer) // Austrian chamber of labor (Arbeiterkammer). URL: https:// ooe.arbeiterkammer.at/service/presse/PKU_2019_Wertschoepfungsbrometer2018 21.01.2019.pdf

22. Barriers to industrial energy efficiency in foundries: a European comparison / Trianni A., Cagno E., Thollander P., Backlund S. / Journal of Cleaner Production. 2013. Vol. 40. P. 161-176. doi: http://doi.org/10.1016/j.jclepro.2012.08.040

23. Empirical investigation of energy efficiency barriers in Italian manufacturing SMEs / Trianni A., Cagno E., Worrell E., Pugliese G. // Energy. 2013. Vol. 49. P. 444-458. doi: http:// doi.org/10.1016/j.energy.2012.10.012

24. A novel approach for barriers to industrial energy efficiency / Cagno E., Worrell E., Trianni A., Pugliese G. // Renewable and Sustainable Energy Reviews. 2013. Vol. 19. P. 290-308. doi: http://doi.org/10.1016/j.rser.2012.11.007

25. Rohdin P., Thollander P., Solding P. Barriers to and drivers for energy efficiency in the Swedish foundry industry // Energy Policy. 2007. Vol. 35, Issue 1. P. 672-677. doi: http://doi.org/ 10.1016/j.enpol.2006.01.010

26. Trianni A., Cagno E. Dealing with barriers to energy efficiency and SMEs: some empirical evidences // Energy. 2012. Vol. 37, Issue 1. P. 494-504. doi: http://doi.org/10.1016/ j.energy.2011.11.005

27. Rasmussen J. The additional benefits of energy efficiency investments - a systematic literature review and a framework // Energy Efficiency. 2017. Vol. 10, Issue 6. P. 1401-1418. doi: http://doi.org/10.1007/s12053-017-9528-1

28. Rasmussen J. Business models to improve industrial efficiency. ECEEE Industrial summer study proceedings Energy efficiency first: The foundation of a low-carbon society. Stockholm, 2011.12 p.

29. Wettbewerbsvorteil Ressourceneffizienz. Berlin: VDI Zentrum Ressourceneffizienz, 2018. 41 p.

30. Energiekosten in verschiedenen Branchen // Energieberaternetzwerk. URL: http://www.energieeffizienz-im-betrieb.net/ energiekosten-unternehmen.html

31. DeCanio S. J., Watkins W. E. Investment in Energy Efficiency: Do the Characteristics of Firms Matter? // Review of Economics and Statistics. 1998. Vol. 80, Issue 1. P. 95-107. doi: http://doi.org/10.1162/003465398557366

32. Cooremans C. Investment in energy efficiency: do the characteristics of investments matter? // Energy Efficiency. 2012. Vol. 5, Issue 4. P. 497-518. doi: http://doi.org/10.1007/s12053012-9154-x

33. Foster R. N. Working The S-Curve: Assessing Technological Threats // Research Management. 1986. Vol. 29, Issue 4. P. 17-20. doi: http://doi.org/10.1080/00345334.1986.11756976

34. Abernathy W. J., Wayne K. Limits of the Learning Curve // Harvard Buiness Review. 1974. URL: https://hbr.org/1974/09/ limits-of-the-learning-curve

35. Röglinger M., Pöppelbuß J., Becker J. Maturity models in business process management // Business Process Management Journal. 2012. Vol. 18, Issue 2. P. 328-346. doi: http://doi.org/ $10.1108 / 14637151211225225$
36. Miller D., Friesen P. H. A Longitudinal Study of the Corporate Life Cycle // Management Science. 1984. Vol. 30, Issue 10. P. 1161-1183. doi: http://doi.org/10.1287/mnsc.30.10.1161

37. Smith K. G., Mitchell T. R., Summer C. E. Top Level Management Priorities In Different Stages Of The Organizational Life Cycle // Academy of Management Journal. 1985. Vol. 28, Issue 4. P. 799-820. doi: http://doi.org/10.2307/256238

38. Quinn R. E., Cameron K. Organizational Life Cycles and Shifting Criteria of Effectiveness: Some Preliminary Evidence // Management Science. 1983. Vol. 29, Issue 1. P. 33-51. doi: http://doi.org/ 10.1287 /mnsc. 29.1 .33

39. Wendler R. The maturity of maturity model research: A systematic mapping study // Information and Software Technology. 2012. Vol. 54, Issue 12. P. 1317-1339. doi: http://doi.org/ 10.1016/j.infsof.2012.07.007

40. Howard D., Hine D. The Population of Organisations Life Cycle (POLC): Implications for Small Business Assistance Programs // International Small Business Journal: Researching Entrepreneurship. 1997. Vol. 15, Issue 3. P. 30-41. doi: http:// doi.org/10.1177/0266242697153002

41. Daft R. L. Organization Theory and Design. St. Paul: South Western College Publishing, 1998. 602 p.

42. Burgelman R., Christensen C., Wheelwright S. Strategic management of technology and innovation. Boston: McGraw Hill, 2008.

43. Promoting industrial energy efficiency // Consorzio per l'AREA di Ricerca Scientifica e Tecnologica di Trieste. URL: http:// www.pineaudit.eu/eng/resources.aspx

44. Energy efficiency in small and medium enterprises: Lessons learned from 280 energy audits across Europe / Fresner J., Morea F., Krenn C., Aranda Uson J., Tomasi F. // Journal of Cleaner Production. 2017. Vol. 142. P. 1650-1660. doi: http:// doi.org/10.1016/j.jclepro.2016.11.126

45. Qualitative and quantitative modelling to build a conceptual framework to identify energy saving options: case study of a wire producing company / Krenn C., Weichbold T., Korp G., Meixner E., Stockner H., Berger D. et. al. // Journal of Cleaner Production. 2015. Vol. 95. P. 212-222. doi: http://doi.org/ 10.1016/j.jclepro.2015.02.052

46. Global energy investment in 2017 fails to keep up with energy security and sustainability goals // International Energy Agency. URL: https://www.iea.org/newsroom/news/2018/july/globalenergy-investment-in-2017-.html

Fresner Johannes, Doctor of Technical Sciences, STENUM Unternehmensberatung und Forschungsgesellschaft für Umweltfragen mbH, Graz, Austria, e-mail: johannes.fresner@stenum.at, ORCID: http://orcid.org/0000-0001-7560-0463

Krenn Christina, STENUM Unternehmensberatung und Forschungsgesellschaft für Umweltfragen $\mathrm{mbH}$, Graz, Austria, e-mail: c.krenn@stenum.at, ORCID: http://orcid.org/0000-0003-4706-555X

Kleshchov Anton, PhD, Resource Efficient and Cleaner Production Centre, Kyiv, Ukraine, e-mail: anton.kleshchov@gmail.com, ORCID: http://orcid.org/0000-0002-9412-4156

Tomasi rabio, Doctor

Tomasi Fabio, Doctor of Political Sciences, AREA Science Park, Trieste, Italia, e-mail: fabio.tomasi@areasciencepark.it, ORCID: http://orcid.org/0000-0002-4036-7857 